\title{
Role of high and low energy seagrass beds as nursery areas for Penaeus duorarum in North Carolina
}

\author{
Patricia L. Murphey, Mark S. Fonseca \\ National Marine Fisheries Service, NOAA, Southeast Fisheries Science Center, Beaufort Laboratory, 101 Pivers Island Road, \\ Beaufort, North Carolina 28516, USA
}

\begin{abstract}
Penaeus duorarum (Burkenroad), pink shrimp, were sampled with a benthic sled, monthly at night on flooding spring tides for $1 \mathrm{yr}$ in high energy patchy seagrass beds and low energy continuous seagrass beds. These beds were located in Back Sound, near Beaufort, North Carolına, USA, and consisted of Halodule wrightii and Zostera marina. Significantly more shrimp were caught in low energy grassbeds than in high energy grassbeds. When shrimp density was weighted for seagrass coverage however, differences in density, while still significant, were much less. Population distribution patterns demonstrated larger shrimp utilized patchy grassbeds in the fall. Despite the variation in spatial configuration of seagrass beds, all tended to provide habitat for $P$. duorarum. Findings from this study support protection of patchy beds as well as continuous beds.
\end{abstract}

KEY WORDS: Seagrass Penaeus Spatial heterogeneity Nursery area Patchy

\section{INTRODUCTION}

As development pressures increase on coastal ecosystems, the need to understand the functional role of seagrass ecosystems has risen (Thayer 1992). It has been suggested that seagrass beds of different spatial arrangement might influence faunal composition and abundance (Fonseca et al. 1983). Therefore, it is essential to focus on potential management implications of spatially distinct patterns of seagrass habitat formation, and understand what fishery resource attributes may be related to this range of spatial variation.

Seagrass habitats in the Beaufort, North Carolina (USA) area exist across a broad spectrum of spatial organization. Highly mounded patchy beds several meters wide form in areas of high energy, due to exposure to waves and/or tidal currents, while low relief, more continuous beds (100s of $\mathrm{m}$ in width) form in low energy areas (sensu Fonseca et al. 1983). These bedforms represent different degrees of sediment stabilization, flow reduction, patch size, and potential protection of faunal inhabitants from predation. Most seagrass research has occurred in beds of continuous cover (e.g. Heck \& Thoman 1984, Lewis 1984, Heck et al, 1989, Fredette et al, 1990), however the extrapolation of functional attributes from continuous cover to patchy beds may not be appropriate.

In this study, we compared the relative abundance of the commercially important pink shrimp, Penaeus duorarum (Burkenroad), in continuous and patchy seagrass beds of southern Core Sound, North Carolina. These patchy and continuous cover seagrass beds, dominated by Zostera marina and Halodule wrightii, represent areas of high and low water motion, respectively (pers. obs.)

Although there have been many studies regarding the temporal sequence of various life history stages of Penaeus duorarum as they occur in North Carolina waters (Williams 1955a, b, 1958, 1959, 1969, McCoy 1968, 1972, Sick 1970, Purvis \& McCoy 1972), only Williams (1955a, b, 1958) specifically recognized seagrass beds as pink shrimp nursery areas. Areas with Halodule wrightii and Zostera marina beds in Core Sound had substantial juvenile shrimp populations 
(Williams 1955a). Noble \& Munroe (1991), in a study of nursery areas in Pamlico Sound, North Carolina, recognized these same areas as being critical habitats, providing food and cover for young finfish and crustaceans.

From these past studies, the life history of Penaeus duorarum in southern Core Sound is relatively well understood. Postlarval (total length, $\mathrm{TL}_{r}<17 \mathrm{~mm}$ ) pink shrimp begin migration into the estuaries in the spring. with highest immigration from offshore waters occurring from June to October. Later immigrants overwinter until the following spring (Williams 1964). Migration of overwintering shrimp out of the estuary is stimulated by rising springtime water temperatures. Somatic growth is correlated with increasing water temperatures (Purvis \& McCoy 1972), and is arrested by cooler temperatures in the fall when shrimp burrow into the substrate. Survivors of this overwintering segment constitute the spring pink shrimp fishery in Pamlico and Core Sounds.

Our purpose for this investigation was to determine whether seagrass beds of different spatial configuration in different physical settings support equivalent abundances of this economically valuable shrimp species. This study compared abundance of Penaeus duorarum in continuous cover and patchy seagrass beds The objectives were to (1) compare utilization of continuous cover, low energy grassbeds and patchy, high energy grassbeds by penaeid shrimp, and (2) compare the temporal colonization patterns of penaeid shrimp among low and high energy regime grassbeds.

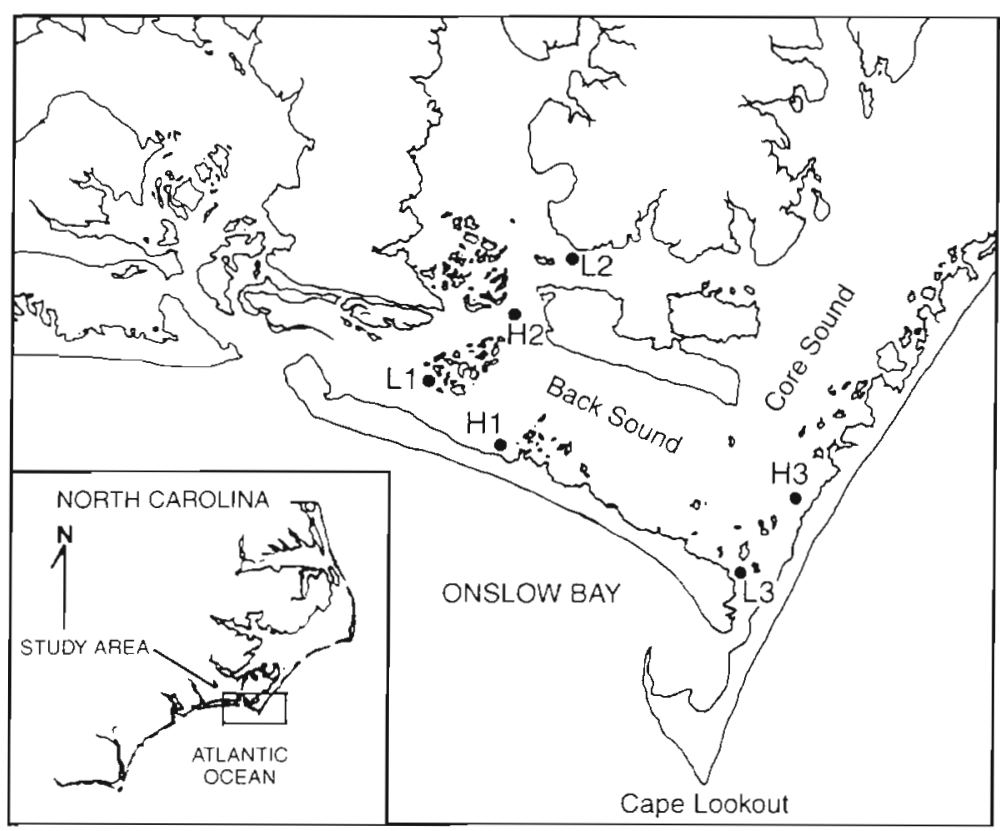

Fig. 1. Locations of high energy sites ( $\mathrm{H} 1$ to 3 ) and low energy sites ( $\mathrm{L} 1$ to 3 ) in Core Sound and Back Sound, North Carolina, USA

\section{METHODS}

Site selection. Based on aerial photographs and field inspections, 3 high energy, patchy seagrass beds and 3 low energy, continuous seagrass beds, all consisting mostly of Halodule wrightii with a mix of Zostera marina and/or Ruppia maritima in Back Sound, North Carolina, were selected (Fig. 1). A preliminary assessment of seagrass coverage, wave exposure, sediment particle size and organic matter confirmed 3 sites to be high energy and 3 sites to be low energy. In addition, environmental data (e.g. tidal stage, wind speed and direction, current speed, water temperature, depth, salinity and sample time) were taken at each station during each faunal sampling period.

Seagrass bed assessment. Exposure index: Fetch length measurements of all study sites were made from a National Oceanic and Atmospheric Administration National Ocean Service nautical chart (11545). Fetch length was converted to effective fetch to describe the influence of irregular shorelines on the wave energy of a particular site (U.S. Army Coastal Engineering Research Center 1977, Keddy 1982). Effective fetch for each of 8 wind directions ( $N, N E, E$, SE, S, SW, W, NW) was calculated for each site. Average monthly maximum wind speed for these 8 directions was calculated over the year previous to shrimp sampling (February 1990 to January 1991) from a NOAA National Weather Service meteorological station at Cape Lookout, North Carolina (within $10 \mathrm{~km}$ of sampling stations). Exposure index (Keddy 1982) was calculated for all sites using the formula:

$$
\operatorname{Exp}=\sum_{j=1}^{8}\left(V_{i} \times P_{7} \times F_{i}\right)
$$

where $i$ is $i$ th compass heading (1 to 8$)_{i} V$ is average monthly maximum wind speed in $\mathrm{m} \mathrm{s}^{-1} ; P$ is percent frequency with which wind occurred from the ith direction; and $F$ is effective fetch.

Sediment analysis: In June and September 1991, 3 surface (top $3 \mathrm{~cm}$ ) sediment cores with a diameter of $2.5 \mathrm{~cm}$ were taken from arbitrarily located portions of seagrass cover at each site and placed in containers on ice without water or preservatives. These samples were later examined by using wet sieve analysis to calculate particle size. Organic content was estimated from weight loss by combustion at $500^{\circ} \mathrm{C}$. Both techniques are described in Plumb (1981).

Vegetation sampling: Seagrass coverage for each site was determined by 2 
methods. Sites were marked at the corners of a $50 \times$ $50 \mathrm{~m}$ quadrat located in an area where seagrass bedforms appeared to be homogenous. In March 1991, prior to more detailed mapping, thirty $1.0 \mathrm{~m}^{2}$ sections were randomly selected from each quadrat, and coverage estimates were made by placing a $1.0 \mathrm{~m}^{2}$ quadrat subdivided into sixteen $0.062 \mathrm{~m}^{2}$ squares over a selected area. Each of the sixteen $0.062 \mathrm{~m}^{2}$ squares was surveyed for presence or absence of seagrass. In June 1991 a more detailed survey method was used; the $50 \times 50 \mathrm{~m}$ quadrat at each site was marked off by perpendicular transects laid $1.0 \mathrm{~m}$ apart, forming a grid of 2500 squares. Presence or absence of seagrass was recorded for each square, after visual inspection.

Seagrass density, above-ground biomass, and belowground biomass was taken, using $15.2 \mathrm{~cm}$ diameter cores. At each site, 3 cores were randomly taken where seagrass occurred; bare areas in the patchy grassbeds were not sampled. Cores were then rinsed of sediment, bagged and frozen for later analysis. In the laboratory, each core sample was thawed, rinsed again of any sediment, and soaked in $10 \%$ phosphoric acid to remove any calcium carbonate deposits. Afterwards, each core sample was divided into seagrass species and shoot counts were made for density measures. Aboveground plant material and below-ground plant material was also separated by species and dried at $70^{\circ} \mathrm{C}$ to obtain biomass.

Faunal sampling. Three replicate 1 min bottom tows were taken at night on a spring flood tide each month from February 1991 through January 1992 (Fig. 1). Because the 3 tows within a given site (i.e. experimental unt) were subsamples, subsequent statistical analyses were based upon averages over the 3 tows. Samples were taken at night because Penaeus duorarum are nocturnal in habit (McCoy 1972). Tows were made with a $1.0 \mathrm{~mm}$ mesh neuston net mounted on a $0.7 \times 0.3 \mathrm{~m}$ frame roller sled pulled approximately $20 \mathrm{~m}$ behind the boat in an effort to minimize prop wash. Each tow was pulled at approximately $1 \mathrm{~m} \mathrm{~s}^{-1}$ within the marked $2500 \mathrm{~m}^{2}$ area where seagrass coverage was estimated.

Initially, a marker was deployed at the start and end of each tow, and tow distance was calculated by 3 replicate sightings with a range finder so that shrimp densities could be quantified. However, because of difficulties encountered during bad weather, a General Oceanics model 207 bullet type flow meter was calibrated to estimate tow distance and mounted on top of the roller sled. This change took place in August 1991.

Samples were initially placed in $10 \%$ formalin and later changed to $95 \%$ ethyl alcohol. Total length (TL) was recorded for each individual pink shrimp. Samples containing more than 300 Penaeus duorarum were separated into 4 arbitrary size groups by carapace length (CL): postlarval ( $\mathrm{CL} \leq 5 \mathrm{~mm})$, small $(5<\mathrm{CL} \leq 8$ $\mathrm{mm})$, medium $(8<\mathrm{CL} \leq 12 \mathrm{~mm})$, large $(\mathrm{CL}>12 \mathrm{~mm})$. Each size group containing more than 40 shrimp was placed in a Folsom plankton splitter and subdivided 2 to 8 times, depending on original abundance. For each sample, at least 25 individuals were measured in each size group. Total numbers were determined either by direct count or by multiplying the number of shrimp in the final split by the number of splits.

Pink shrimp densities were expressed as either areal density or specific density where:

Areal density $(A D)=$

(Total no. of shrimp)(Tow $)^{-1} /$ Bottom area sampled

Specific density =

$\mathrm{AD} / \%$ Seagrass cover (decimal equiv.)

Areal values represent shrimp densities irrespective of seagrass cover, and represent the normal manner in presenting faunal densities, while specific density weights shrimp density for seagrass coverage (i.e. shrimp per unit of actual seagrass coverage likely encountered during a tow). Previous sampling in the same area, using dropnets, has demonstrated that considerably more Penaeus duorarum occur in seagrass than in bare areas (Fonseca et al. 1990).

Statistical analysis. ANOVA was used to examine the data for significant differences between high energy patchy grassbeds and low energy continuous grassbeds. The statistical model for these analyses included both time and energy level factors, and their interaction. The analysis of shrimp densities was based upon ranks, rather than densities or logarithms of densities, because model residuals for neither of the latter were approximately normally distributed. Kolmogorov-Smirnov 2-sample tests (K-S) (Conover 1980) were used to compare pink shrimp population distributions between energy regimes for each month.

\section{RESULTS}

\section{Seagrass bed assessment}

The exposure index revealed that the 6 sites occurred along an energy gradient of 3 orders of magnitude (Table 1). Percent seagrass coverage was initially used to classify 3 sites as high energy (H1 to H3); coverage ranged from 36 to $67 \%$ with a mean of $51 \%$, while low energy sites (L1 to L3) ranged from 66 to $99 \%$ with a mean of $91 \%$. Coverage for the L1 site $(42 \%)$ during March was low because this grassbed receded from the area. We therefore moved the sample area boundaries approximately $25 \mathrm{~m}$ to where the grassbed was more continuous for subsequent sampling. Final assessment of a site to either high or low 
Table 1. Comparison of exposure and percent of silt/clay, sand, organic matter and seagrass cover. H: high energy; L: low energy sites

\begin{tabular}{|c|c|c|c|c|c|c|}
\hline Site & Month (1991) & Exposure & $\%$ Silt/clay & $\%$ Sand & $\begin{array}{c}\% \text { Organic } \\
\text { matter }\end{array}$ & $\begin{array}{c}\% \text { Seagrass } \\
\text { cover }\end{array}$ \\
\hline \multirow[t]{3}{*}{$\mathrm{H} 1$} & March & & & & & 54 \\
\hline & June & 2171 & 8.09 & 91.82 & 0.77 & 55 \\
\hline & September & 2296 & 18.41 & 81.59 & 1.57 & 32 \\
\hline \multirow[t]{3}{*}{$\mathrm{H} 2$} & March & & & & & 60 \\
\hline & June & 999 & 12.56 & 87.38 & 0.94 & 65 \\
\hline & September & 1056 & 19.59 & 79.25 & 2.37 & 67 \\
\hline \multirow[t]{3}{*}{$\mathrm{H} 3$} & March & & & & & 48 \\
\hline & June & 4587 & 14.42 & 84.58 & 1.36 & 37 \\
\hline & September & 4851 & 16.68 & 83.16 & 1.20 & 36 \\
\hline \multirow[t]{3}{*}{ L1 } & March & & & & & $42^{\mathrm{d}}$ \\
\hline & June & 77 & 23.12 & 76.81 & 2.01 & 99 \\
\hline & September & 81 & 28.80 & 70.79 & 3.29 & 89 \\
\hline \multirow[t]{3}{*}{ L2 } & March & & & & & 98 \\
\hline & June & 194 & 25.93 & 73.93 & 1.54 & 96 \\
\hline & September & 206 & 27.00 & 72.91 & 3.48 & 93 \\
\hline \multirow[t]{3}{*}{ L3 } & March & & & & & 94 \\
\hline & June & 89 & 23.36 & 76.30 & 1.50 & 94 \\
\hline & September & 94 & 17.22 & 72.75 & 3.62 & 66 \\
\hline
\end{tabular}

energy classification was based on a post facto examination of the exposure index (Exp $\geq 999=$ high energy) for each site.

Even though there was overlap of coverage levels among grassbeds classified high and low energy (Table 1), there was a significant difference in mean coverage between the seagrass beds we classified as high and low energy ( $p<0.05$, excluding L1 March). There were no significant differences $(p>0.05)$ in plant density, above-ground biomass and belowground biomass between the patches in the high energy grassbeds and low energy grassbeds nor was there any gradient apparent in plotting biomass versus exposure index (not shown).

As would be expected, sediments in high energy sites were generally coarser, with sand contents exceeding $79 \%$, whereas in low energy sites, sand content was always below $77 \%$. Gravel was negligible to non-existent in all sites. The organic content was also generally greater in low energy sites. While the exposure index was somewhat lower and the percent seagrass cover slightly higher for Site H2, it had siltclay, sand and organic matter characteristics common to the high energy sites; therefore, it was grouped with these sites.

\section{Environmental conditions}

Sled tows were conducted at high flood tides to enable access to the sample sites. Average depths at the 6 sites ranged from 90 to $120 \mathrm{~cm}$. Salinities ranged from 33 to $37 \mathrm{ppt}$ during spring and summer but decreased during fall to a low of 28 ppt in November, returning to a mean of $34 \mathrm{ppt}$ among sites in December. Salinities were generally similar among the sites. Rainfall data for the year (U.S. Weather Service 1991) indicated a $25.4 \mathrm{~cm}$ increase above normal for the sampling year, but during the fall season it was $5.1 \mathrm{~cm}$ below normal. Mean water temperatures ranged from approximately $5^{\circ} \mathrm{C}$ in December to $30^{\circ} \mathrm{C}$ in July. Air temperatures for the year were approximately $2^{\circ} \mathrm{C}$ warmer than average (U.S. Weather Service 1991).

\section{Shrimp densities}

A total of 12939 penaeids, representing 4 species, was collected from 216 tows conducted monthly from February 1991 until January 1992. Total catch was dominated by Penaeus duorarum, making up $91.8 \%$ of the total, followed by brown shrimp Penaeus aztecus $(4.0 \%)$, and Trachypenaeus constrictis $(1.2 \%)$. Two white shrimp Penaeus setiferus were also caught. Damaged, unidentifiable penaeids represented the remaining $3.0 \%$. Of these, approximately $78 \%$ were caught in low energy grass beds, and $22 \%$ were caught in high energy grass beds.

Statistical analyses were only conducted on the Penaeus duorarum densities. On an areal basis, shrimp densities varied significantly between low energy grassbeds and high energy grassbeds and among 
Table 2. Analyses of Variance of areal and specific densities. - Significantly different at $\alpha<0.05$

\begin{tabular}{|lrcc|}
\hline Source & df & Mean Square & $F$ \\
\hline Areal density & & & \\
Among months & 11 & 4.6263 & $13.39^{\circ}$ \\
Between energy levels & 1 & 2.9107 & $12.23^{\circ}$ \\
Month $\times$ energy Level & 11 & 0.3456 & 1.45 \\
Experimental error & 48 & 0.2381 & \\
$\mathrm{R}^{2}=0.83$ & & & \\
Specific density & & & \\
Among months & 11 & 4.8946 & $13.40^{\circ}$ \\
Between energy levels & 1 & 0.8766 & $4.09^{\circ}$ \\
Month $\times$ energy level & 11 & 0.3652 & 1.70 \\
Experimental error & 48 & 0.2145 & \\
$\mathrm{R}^{2}=0.85$ & & & \\
\hline
\end{tabular}

months (Table 2). The greatest differences in densities between the low energy and high energy sites were observed in July and August when areal densities in the low energy sites averaged about 3 times the corresponding values for the high energy sites (Fig. 2). The corresponding analysis of specific density also revealed significant differences among months and between energy regimes (Table 2). However, the specific densities in the low energy sites only averaged about 1.8 times the specific densities in the high energy sites (Fig. 3).

\section{Size frequency}

The overwintering juvenile Penaeus duorarum cohort (18 to $46 \mathrm{~mm}$ TL) was present from February to May (Fig. 4a), during which time mean sizes increased from 35 to $64 \mathrm{~mm}$ TL. There were no significant differences ( $p>0.05$ ) between mean size based on ANOVAs on TL. K-S 2-sample tests also showed no significant differences ( $p>0.05$ ) between the populations found in the high and low energy grassbeds during this time. In June
Fig. 2. Penaeus duorarum. Mean monthly areal densities ( $\pm 1 \mathrm{SD}$ ) in low energy grassbeds (-) and high energy grassbeds (-.---)
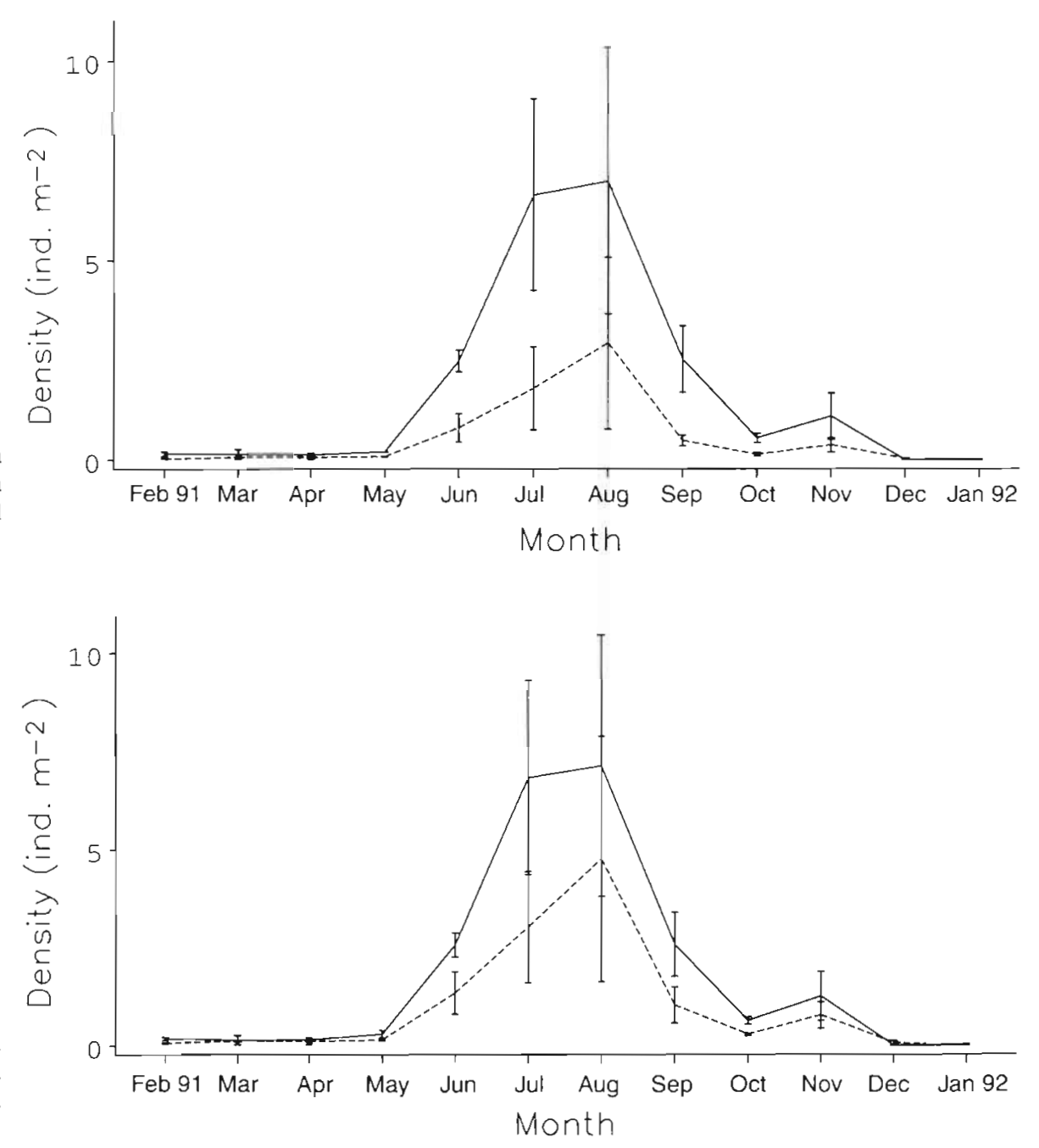

Fig. 3. Penaeus duorarum. Mean monthly specific densities $( \pm 1 \mathrm{SD}$ ) in low energy grassbeds (-) and high energy grassbeds (--.--) 

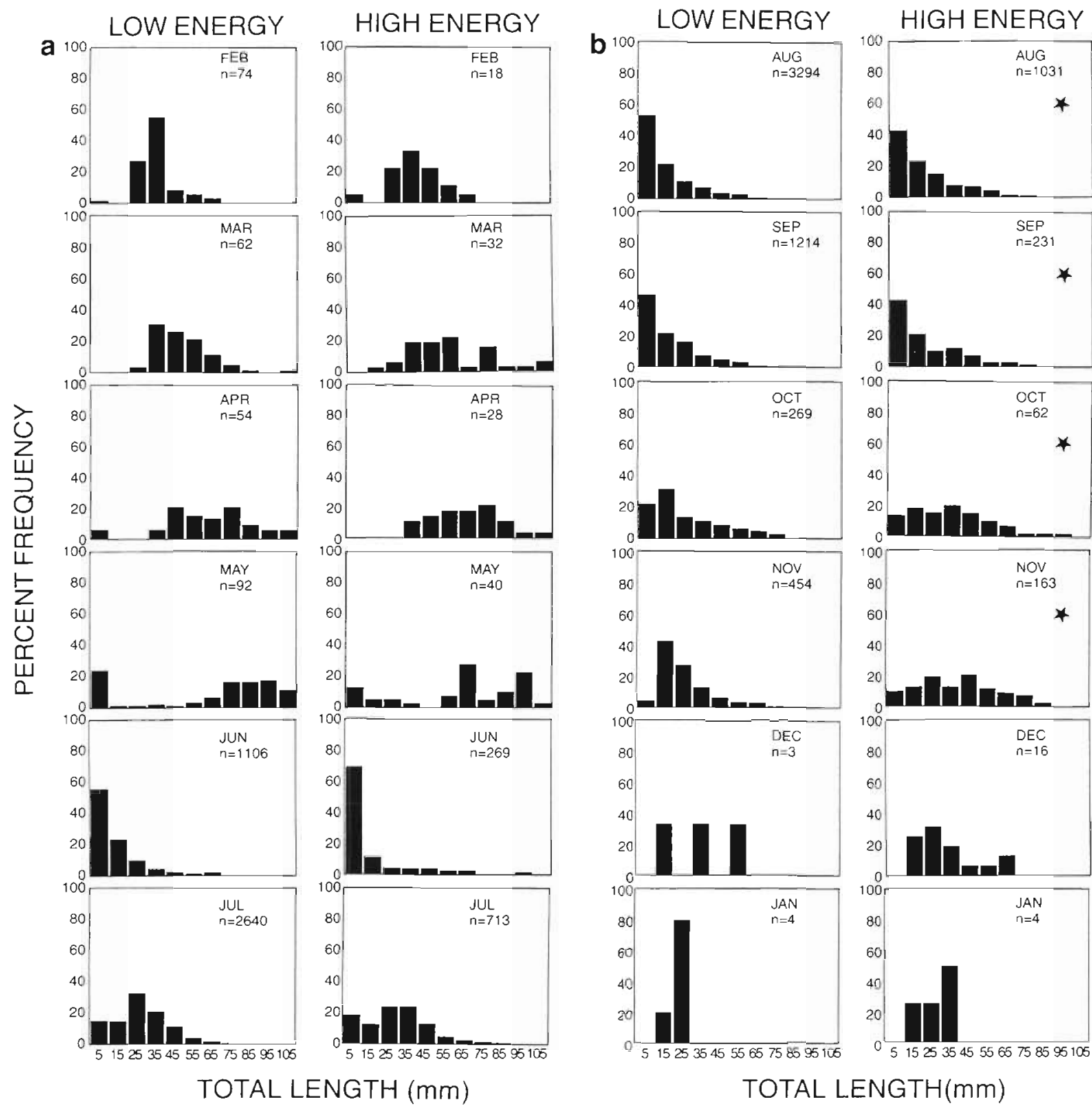

Fig. 4, Penaeus duorarum. Percent frequency distributions (a) from February through July, (b) from August through January in low energy grassbeds and high energy grassbeds. $\star$ : significant differences $(\mathrm{p}<0.05)$. n: total number caught in each energy regime

and July, there were significant differences $(p<0.05)$ between the population distribution of shrimp in the high energy and low energy grassbeds but no significant difference $(p>0.05)$ in mean size. This is probably due to the large sample size taken during this time, enabling the K-S test to detect relatively slight differences between the 2 distributions. July samples consisted mostly of juvenile shrimp, with a second major influx of postlarval shrimp occurring in August (Fig. 4b). There were significant differences $(p<0.05)$ between mean size and population distribution in the high energy and low energy grassbeds from August through November. During this period, mean shrimp size was larger in the high energy grassbeds. In December and January there were no significant differences $(p>0.05)$ in mean size or population distribution which consisted mostly of overwintering juvenile shrimp in both the high energy grassbeds and the low energy grassbeds. Again, overwintering shrimp numbers may be low due to net avoidance by burrowing at this time of year. 


\section{DISCUSSION}

As might be expected in a habitat with more seagrass coverage per unit area, significantly greater shrimp densities were found in low energy seagrass beds than in the high energy seagrass beds on an areal basis. Specific density (coverage-weighted) computations of shrimp densities also revealed significant differences between high and low energy sites, but to a lesser degree. Since there was little fluctuation in salinity during this study, it does not appear that this parameter had much influence on shrimp density.

This study has demonstrated that patchy seagrass beds typically found in high energy sites are important habitats for Penaeus duorarum. Although they do not support as great a density of shrimp as continuous seagrass beds in low energy situations (Figs. 2 \& 3), they nevertheless support a substantial density of pink shrimp and deserve serious consideration in management issues. Historically, permitting agencies have considered patchy seagrass beds to be expendable. Permits are often issued in these areas, although federal and state management agencies recommend against issuing those permits (L. Hardy, NMFS Habitat Conservation Division, Beaufort, NC, field office, pers. comm.). Spatial heterogeneity alone should not be used to justify destruction of patchy seagrass beds in construction permit requests. While not evaluated in this paper, it is possible that these findings may hold for species other than $P$. duorarum.

\section{Shrimp life history}

From winter until late spring, pink shrimp densities remained low relative to summer densities for both high and low energy grassbed areas. While sampling in Core Sound during winter months with a suction sampler, McCoy (1968) found numerous shrimp buried in the sediment. Buried pink shrimp would have been missed during winter by our epibenthic sampling gear.

Apparent migration of Penaeus duorarum to the study sites was seasonal as expected (Williams 1955a, b, McCoy 1968, 1972, Purvis \& McCoy 1972). There was little movement in the winter, and shrimp caught then were likely overwintering juveniles. There was no difference in size or population in the winter in either high or low energy grassbeds. By summer, slight differences in the population distributions existed with no differences in size until August when size and population distributions were different between the energy regimes. During this period, and extending through November, high energy grassbeds had larger shrimp than low energy grassbeds. In the winter, when overwintering shrimp numbers are low, both types of grassbeds support equivalent shrimp densities. However, as temperature increased and shrimp became more active, there was a change in the population distribution with more postlarval shrimp using the low energy grass beds than the high energy grassbeds. By August and throughout the fall months, when differences in population distribution and size began to appear, there were larger shrimp utilizing the higher energy grassbeds than in the low energy grassbeds

Several mechanisms may be responsible for the presence of larger shrimps in the high energy beds in the fall. It has been established that inshore and offshore movements of postlarval and juvenile pink shrimp are facilitated by the selective use of tidal currents (Hughes 1972). Larger shrimp may tend to inhabit the patchy beds in the fall in order to position themselves in the higher current area to facilitate their movement out of the estuary to reach offshore spawning grounds. It may simply be that larger shrimps are better capable of maneuvering in the higher wave and/or current regime. Rulifson (1981) found that size influenced Penaeus aztecus in substrate selection. Aggregations were limited by density $\left(\mathrm{g} \mathrm{m}^{-2}\right)$, therefore dispersing themselves according to the loading capacity of the substrate. Rulifson (1981) found no sizeassociated habitat preference using Penaeus duorarum. However, he stated that he had insufficient sample size, therefore additional testing is warranted. It has also been demonstrated that crowding may adversely influence growth and survival in the western king prawn Penaeus latisulcatus in Australia due to less efficient feeding (Rasheed \& Bull 1992). If this is the case, the potential segregation of Penaeus duorarum by size may be habitat specific (e.g high vs low energy habitats). Reasons for this segregation may include reduced intraspecific competition during winter months when feeding is reduced or one of any number of ontogenetically linked factors relating to habitat preference and feeding requirements. Any indication of habitat specific size ranges warrants further investigation as it may provide important new insights as to ontogenetic habitat requirements.

We conclude that despite the various spatial configurations of seagrass beds near Beaufort, all tended to function as habitat for all sizes of Penaeus duorarum. Research should be conducted on effects of patch size on mechanisms influencing population structure and density of $P$. duorarum over different seasons. While additional work is required to define the role of spatial configuration, our results support protection of patch beds, even in the winter season, because of the likely benefit to the spring pink shrimp fishery in North Carolina. 
Acknowledgements. The authors thank S. Dipiero, P. Whitfield, M. LaCroix, E. Townsend, P. McCann, M. Hesik, G. Thayer, J. Rivera, D. Meyer, and C. Escalante for their assistance in sampling on schedule, despite the weather and the tides which never seemed to give us a break. We also thank W. Hettler, G. Thayer, P. Sheridan, and E. Wenner for their review comments, D. Colby and $M$. Crawford for their statistical assistance and A. Williams for his help in confirming postlarval penaeid shrimp identifications. Funding for this research was provided by NOAA's Coastal Ocean Program (EHP-23) to M. Fonseca and matching funds by the Beaufort Laboratory of the National Marine Fisheries Service.

\section{LITERATURE CITED}

Conover WJ (1980) Practical nonparametric statistics, 2nd edn. John Wiley and Sons, New York

Fonseca MS, Kenworthy WJ, Colby DR, Rittmaster KA, Thayer GW (1990) Comparisons of fauna among natural and transplanted eelgrass Zostera marina meadows: criteria for mitigation. Mar Ecol Prog Ser 65:251-264

Fonseca MS, Zieman JC, Thayer GW, Fisher JS (1983) The role of current velocity in structuring eelgrass (Zostera marina) meadows. Estuar coast Shelf Sci 17:367-380

Fredette TJ, Diaz RJ, Van Montfrans J, Orth RJ (1990) Secondary production within a seagrass bed (Zostera marina and Ruppia maritima) in lower Chesapeake Bay. Estuaries 13:431-440

Heck KL, Able KW, Fahay MP, Roman CT (1989) Fishes and decapod crustaceans of Cape Cod eelgrass meadows: species composition, seasonal abundance patterns and comparison with unvegetated substrates. Estuaries 12: $59-65$

Heck KL, Thoman TA (1984) The nursery roles of seagrass meadows in the upper and lower reaches of the Chesapeake Bay. Estuaries 7:70-92

Hughes DA (1972) On the endogenous control of tide-associated displacements of pink shrimp, Pendeus duorarum Burkenroad. Biol Bull 142:271-280

Keddy PA (1982) Quantifying within-lake gradients of wave energy, substrate particle size and shoreline plants in Axe Lake Ontario. Aquat Bot 14:41-58

Lewis FG (1984) Distribution of macrobenthic crustaceans associated with Thalassia, Halodule and bare sand substrata. Mar Ecol Prog Ser 19:101-113

McCoy EG (1968) Migration, growth and mortality of North Carolina pink and brown shrimp. NC Dept Conserv Devel, Spec Sci Rep 15

This article was presented by K. L. Heck (Senior Editorial Advisor), Dauphin Island, Alabama, USA
McCoy EG (1972) Dynamics of North Carolina commercial shrimp populations. NC Dept Natur Econ Res, Spec Sci Rep 21

Noble EB, Monroe RJ (1991) Classification of Pamlico Sound nursery areas: recommendation for critical habitat criteria. NC Dept Environ Health Natur Resour, Div Mar Fish Proj 89-09

Plumb RH (1981) Procedures for handling and chemical analysis of sediment and water samples. Environmental Laboratory, US Army Engineer Waterways Experiment Station, Vicksburg, MS

Purvis CE, McCoy EG (1972) Overwintering pink shrimp, Penaeus duorarum in Core and Pamlico Sounds, N.C. NC Dept Natur Econ Res, Spec Sci Rep 22

Rasheed MA, Bull CM (1992) Behavior of the western king prawn, Penaeus latisulcatus Rishinouye: effect of food dispersion and crowding. Aust $J$ mar Freshwat Res 43: $745-752$

Rulifson RA (1981) Substrate preferences of juvenile penaeid shrimps in estuarine habitats. Contrib mar Sci 24:35-52

Sick LV (1970) Larval distribution of commercially important Penaeidae in North Carolina. J Elisha Mitchell Sci Soc 86: $118-127$

Thayer GW (1992) The science of restoration: status and directions. In: Thayer GW (ed) Restoring the nation's marine environment. Maryland College, College Park, p $1-5$

Thayer GW, Kenworthy WJ, Fonseca MS (1984) The ecology of eelgrass meadows of the Atlantic coast: a community profile. Res Rep US Fish Wildl Serv, FWS/OBS-84/02

U.S. Army Coastal Engineering Research Center, Shore Protection Manual (1977). Ft Belvoir, VA

U.S. National Weather Service (1991) Climatological data: North Carolina. 96:11, 13

Williams $A B$ (1955a) A contribution to the life histories of commercial shrimps (Penaeidae) in North Carolina. Bull mar Sci Gulf Caribb 5:116-147

Williams $A B$ (1955b) A survey of North Carolina shrimp nursery grounds. J Elisha Mitchell Sci Soc 71:200-207

Williams AB (1958) Substrates as a factor in shrimp distribution. Limnol Oceanogr 3:283-290

Williams AB (1959) Spotted and brown shrimp postlarvae (Penaeus) in North Carolina. Bull mar Sci Gulf Caribb 9: $281-290$

Williams AB (1964) A postlarval shrimp survey in North Carolina. NC Dept Devel, Spec Sci Rep 3

Williams AB (1969) A ten-year study of meroplankton in North Carolina estuaries: cycles of occurrence among penaeidean shrimps. Chesapeake Sci 10:36-47

Manuscript first received: April 29, 1994

Revised version accepted: December 21, 1994 